\title{
LATVIJAS UNIVERSITĀTES DIBINĀŠANAS JURIDISKIE ASPEKTI
}

\section{Sanita Osipova}

Dr. iur., profesore, Latvijas Universitātes Juridiskā fakultāte.

Zinātniskās intereses: tiesību vēsture, jurista ētika, tiesību sociologija. Šobrīd strādā pie kolektīvās monogrāfijas Tiesības informācijas sabiedrībā.

2019. gads ir Latvijas Universitātes simtgades gads, tāpēc pētījuma ietvaros tiek analizēti Latvijas Universitātes dibināšanas juridiskie aspekti un tās sociāli politiskā nozīme Latvijas Republikā. Latvijas Universitātes Satversmes Preambulā un citos avotos universitātes dibināšana juridiski sadalīta divās daḷās: rīkojumu par LU dibināšanu 1919. gada 8. februārī esot pieņēmis Pēteris Stučka, bet faktisko atklāšanu 28. septembrī veicis Jānis Čakste. Pētījumā noskaidrots, ka šis padomju laika koncepts par LU dibināšanu neatbilst patiesībai. Latvijas Tautas padome 1919. gada 15. jūlijā lēma dibināt jaunu Latvijas Augstskolu, nevis atjaunot kādu no iepriekš Latvijas teritorijā pastāvējušajām. Tieši Latvijas Tautas padomes lēmums līdz ar Pagaidu valdības 1919. gada 2. augustā izdoto rīkojumu šì lēmuma īstenošanai ir uzskatāmi par LU dibināšanas juridisko pamatu.

Atslēgas vārdi: nacionāla augstskola, Latvijas Universitātes dibināšana.

\section{IEVADS}

Raksta autore 1986. gadā iestājās studēt jurisprudenci Pētera Stučkas Latvijas Valsts universitātē. Tikai dažus gadus vēlāk, pēc Latvijas Republikas valstiskuma atjaunošanas, universitāte atguva Latvijas Universitātes (turpmāk - LU) vārdu. Tika atgūta vēsturiskā LU simbolika, kā arī apstiprināta jauna Latvijas Universitātes Satversme. ${ }^{1}$ Universitātes atjaunotne 1990./1991. gadā gāja kopsolī ar Latvijas Republikas neatkarības atgūšanu.

2019. gads ir Latvijas Universitātes simtgades gads, tāpēc autore šì pētījuma ietvaros, analizējot normatīvos aktus, 
Latvijas Tautas padomes sēžu stenogrammas, Latvijas Universitātes Organizācijas padomes atstātos dokumentus, kā arī citus arhīva un preses materiālus, pētīs Latvijas Universitātes dibināšanas juridiskos aspektus un tās sociāli politisko nozìmi Latvijas Republikā. ${ }^{2}$

Tēmas izvēli noteica zinātniskajā literatūrā un sabiedriskajā domā valdošie atšḳirīgie viedokḷi par Latvijas Universitātes dibināšanas datumu un dibinātāju. Padomju Savienības okupācijas laikā tika uzsvērts, ka Latvijas Universitāti ir dibinājis Latvijas Sociālistiskās Padomju Republikas vadītājs Pēteris Stučka (18651932), un kā universitātes dibināšanas datums tika minēts 1919. gada 8. februāris. Turklāt tika skaidrots, ka vēlāk "buržuāziskajā Latvijā” uz P. Stučkas dibinātās augstskolas bāzes esot veidota Latvijas Universitāte. ${ }^{3}$ Arī Atmodas laikā (19861990/1991) netika pārskatīta padomju periodā popularizētā Latvijas Universitātes vēsture, proti, Latvijas Universitāte ir tā pati P. Stučkas dibinātā Latvijas Augstskola. Ilgonis Bite laikrakstā “Literatūra un Māksla” 1989. gada 4. februārī, godinot Latvijas Universitātes 70. jubileju, rakstīja: "lielinieku varas vīri piegrieza nopietnāko vērību augstskolas dibināšanai un izveidošanai, un jau apmēram vienu mēnesi pēc viņu ienākšanas Rīgā izdeva dekrētu (1919. g. 8. februārī, parakstījis P. Stučka) par Padomju Latvijas augstskolu [..] Tāds bija LVU [Latvijas Valsts universitātes] tapšanas pirmais akords. Taču Latvijas augstskolu atklāj 1919. gada 28. septembrī, jau Tautas padomes prezidentam J. Čakstem piedaloties." 4 Šāda koncepcija universitātes dibināšanu juridiski sadalīja divās daḷās, jo juridisko pamatu esot ielicis P. Stučka, bet faktisko atklāšanu veicis jau Jānis Čakste (1859-1927). Gan vēsturiski, gan juridiski tas rosina pārdomas, jo P. Stučka un J. Čakste pārstāvēja divas dažādas valstis, turklāt katra no tām bija otras noliegums. Starpkaru laika publikācijās par Latvijas Universitātes dibināšanu tika skaidri norādīts, ka pamatu tās tiesiskai pastāvēšanai lika Pagaidu valdības 1919. gada 2. augustā izdotais rīkojums. ${ }^{5}$ Arī pēc Otrā pasaules 
kara trimdā publicētajos viedokḷos tika uzsvērts, ka Latvijas Universitāti dibinājusi Latvijas Republika. ${ }^{6}$

Kopš Atmodas laika ir pagājuši 30 gadi, un Latvijas Universitātes dibināšanas juridiskajām peripetijām vajadzētu būt atrisinātām. Taču tas tā nav, jo padomju laika skatījums uz Latvijas Universitātes dibināšanu ticis iekḷauts arī 1991. gada 18. septembrī Latvijas Republikas Augstākās padomes apstiprinātās Latvijas Universitātes Satversmes Preambulā. ${ }^{7}$ Proti, vēsturiski apšaubāmi fakti ir tikuši juridiski fiksēti! Jāatzīmē, ka arī spēkā esošās Latvijas Universitātes Satversmes redakcijas Preambulas teksts būtiski neatšşiras. ${ }^{8}$

Arī Latvijas Universitātes mājaslapā, raksturojot augstskolas vēsturi, ir piesardzīgi apiets dibināšanas juridiskais pamats, proti, tas vispār nav minēts. ${ }^{9}$ Taču par pašu dibināšanas datumu netiek piel̦autas šaubas: "Latvijas Universitāte (LU) dibināta 1919. gada 28. septembrī."10 Tomēr minētajā datumā, kas šobrīd tiek svinēts kā LU dibināšanas diena, notika tikai svinīgais atklāšanas akts, kas bija zināmu priekšdarbu, tostarp juridisku lēmumu rezultāts. Par valsts universitātes dibināšanu var lemt tikai pati valsts. Tāpēc būtisks ir jautājums: "Kad tika pieņemts politisks lēmums vai normatīvs akts par LU dibināšanu, kas kalpoja par tālāko procesu, proti, LU faktiskās dibināšanas 1919. gada 28. septembrī juridisko pamatu?”

Padomju varas gados tika godināts normatīvā akta, proti, dekrēta "Par Latvijas augstskolas dibināšanu" pieņemšanas datums - 1919. gada 8. februāris. ${ }^{11}$ Savukārt tagad tiek atzīmēta LU svinīgā atklāšanas akta diena, proti, 1919. gada 28. septembris, nepievēršot uzmanību politiskiem lēmumiem, kas deva juridisku pamatu dibināt nacionālo universitāti.

Lìdz mūsdienām ir publicēta virkne grāmatu par Latvijas Universitāti. Uz katru apalıu universitātes gadskārtu svinīgi ir laista klajā jauna grāmata. Tradīcija, kas aizsākta starpkaru posmā 1929. gadā, atzīmējot LU pastāvēšanas 10 gadus, tikusi turpināta padomju varas gados un arī pēc Latvijas Republikas 
neatkarības atjaunošanas. ${ }^{12}$ Liekas, ka grāmatas ir veltītas vienai un tai pašai augstākajai mācību iestādei, taču tajās būtiski atšķiras ne tikai augstskolas nosaukums un tās valstiskie uzdevumi, bet arī minētie fakti par universitātes dibināšanu un augstskolu pēctecību, proti, vai Latvijas Universitāte, kuru dibināja Latvijas Republika, ir Pētera Stučkas Latvijas Sociālistiskās Padomju Republikas valdības dibinātās Latvijas Augstskolas pēctece, vai arī tā ir, kā to rakstīja padomju literatūrā, viena un tā pati universitāte. Šo jautājumu vēl vairāk sarežg̀ī fakts, ka Latvijas Universitāte 1919. gada 28. septembrī tika atklāta kā Latvijas Augstskola $^{13}$ un vairākus gadus pēc dibināšanas (līdz 1923. gadam) paralēli tika lietoti abi minētie nosaukumi. ${ }^{14}$ Tāpēc pētījuma uzdevumi ir gan izpētīt Latvijas Universitātes dibināšanas procesu, vienlaikus akcentējot latviešu augstskolas sociālo nozīmi un valstiskos uzdevumus, gan arī to, vai Latvijas Universitāte ir P. Stučkas dibinātās Latvijas Augstskolas pēctece.

\section{AUGSTĀKĀ IZGLĪTĪBA DZIMTAJĀ VALODĀ}

Doma, ka ikvienai nācijai ir nepieciešama augstākā izglītība un zinātne nacionālā valodā un nacionāla universitāte, kas to īsteno, tika skaidri definēta 19. gs. beigās/20. gs. sākumā. Tā auga un veidojās līdz ar izpratni par izglìtības un zinātnes nozīmi pilsoniskā sabiedrībā. Jau kopš 19. gs. sākuma, kad Vilhelms fon Humbolts (Wilhelm von Humboldt, 1767-1835) lika pamatu mūsdienu izpratnei par augstāko izglītību un universitātes misiju valstī, universitātes tiek aplūkotas kā sabiedriski un valstiski nozīmīgi izglītības un zinātnes centri, ${ }^{15}$ kas kalpo par nācijas pilnvērtīgas, vispusīgas attīstības pamatu.

Ideja par augstāko izglītību dzimtajā valodā attīstījās kopsakarā ar nacionālo emancipāciju un nacionālas valsts konceptu. Nacionāla valsts tika aplūkota gan kā iespēja tautai izdzīvot, saglabājot savu patību, gan kā tās neatṇemamas tiesības. ${ }^{16}$ Ideju par tautas tiesībām uz savu valsti 19. gs. gaitā visupirms sekmēja 
nacionālās pašapziṇas veidošanās aizvien jaunās nācijās, tostarp lietuviešos, igauņos, somos un latviešos. Tā latvieši no agrāras, patriarhālas sabiedrības pēc dzimtbūšanas atcelšanas dažu paaudžu laikā izveidojās par moderno laiku nāciju ar izteikti kulturālu un augošu pašapziņu. ${ }^{17}$ Nenoliedzami, idejas par katras nācijas tiesībām uz savu valsti nostiprināšanos sekmēja arī impēriju kopš 19. gs. otrās puses piekoptā agresīvā "mazo tautiṇu vajāšanas" politika. ${ }^{18}$

Jaunas nacionālas universitātes nepieciešamību Latvijā noteica visupirms nepieciešamība pēc docēšanas un pētniecības valodas maiņas, proti, jaunajai valstij bija jauna valsts valoda. Valoda ir būtisks ikvienas sabiedrības raksturlielums, saliedētājs un kolektīva vērtība. Valoda l̦auj nodrošināt sabiedrības ilgtspēju un tajā pastāvošo sarežgìito attiecību, vajadzību un vērtību verbalizāciju, sniedzot iespēju personām brīvi sazināties. Niklass Lūmans (Niklas Luhmann, 1927-1998) ${ }^{19}$ uzsver, ka "sabiedrība nav spējīga iziet ārpus tām robežām, kuras tiek nospraustas valodā". ${ }^{20}$ Proti, katrā sabiedrībā valodas robežas vienlaikus ir arī iespējamās komunikācijas robežas. Tāpēc, veidojot jaunus sociālus institūtus, attiecības, iepazīstot jaunus apvāršnus mākslā un zinātnē, jāpilnveido arī valoda. Turklāt valsts valoda $\operatorname{līdz}$ ar citām valodas sociālajām funkcijām veic arī specifiskus valstiski svarīgus uzdevumus, jo nodrošina valsts funkcionēšanu un komunikāciju starp personu un valsti. ${ }^{21}$

Valoda ir jākopj un jāpilnveido. Tās attīstību visupirms nodrošina pilnvērtīga lietošana visās sociālo attiecību jomās. Savukārt valodas lietojums izglītībā un zinātnē ir īpaši svarīgs, lai veidotu nāciju par modernu kultūras nāciju. Tātad augstākā izglītība valsts valodā ir valstiski svarīga, jo sekmē valsts valodas attīstību un tālāko tās pielietojumu visās dzīves jomās: gan sadzīvē, gan valsts pārvaldē, gan zinātnē. To apzinājās arī latviešu valstsvīin. Latvijas Tautas padomes priekšsēdētājs Jānis Čakste, sakot uzrunu LU atklāšanā, uzsvēra: “Tagad, kur latviešu tauta ņēmusi pati savās rokās sava likteņa izšķiršanu, savas gaitas 
iekārtošanu un vadību, viens no pirmajiem uzdevumiem bija nodibināt savu pašu augstskolu - savu pašu gaismas pili." ${ }^{22}$ Latvijas Augstskolas dibināšana laikabiedru acīs tika vērtēta kā nācijas uzplaukuma pamats, pielīdzinot to nacionālās pašapziṇas simbolam “Gaismas pilij”. Nacionālajā presē Latvijas Augstskolas atklāšana pēc nozīmes tika salīdzināta pat ar Latvijas valsts proklamēšanu 1918. gada 18 . novembrī. ${ }^{23}$

Jaunai nācijai realizējot tiesības uz savu valsti, šai nācijai piederīgie vienlaikus ieguva tiesības uz izglītību dzimtajā valodā visos izglītības līmeņos. Bieži tā bija pirmā reize šīs nācijas vēsturē, kad tika nodrošināta iespēja studēt konkrētā "mazās tautiņas" ${ }^{24}$ valodā, kā tas bija, piemēram, somu, igauņu un latviešu valodā. Impēriju izglītības sistēmā tika ierobežota vai pilnībā liegta iespēja mācīties un studēt valodās, kas nebija valsts valoda. Mācībspēki 19. gs. daudzās valstīs kḷuva par valsts ierēdņiem. Izglītības sistēmā valdīja cenzūra, ierobežojot gan vārda brīvību, gan valodas lietojumu valsts izglītības iestādēs. Jo īpaši 19. gs. beigās, impērijās nostiprinoties nacionāliem noskaņojumiem, tostarp augot titulnācijas nacionālajai pašapziņai, tika likts uzsvars uz obligātu valsts valodas lietošanu visās mācību iestādās, arī universitātēs. Piemēram, tajā Polijas daḷā, kas 18. gs. beigās tika pievienota Krievijas impērijai, sākotnēji tika aț̣auts mācību iestādēs docēt poḷu valodā. Taču 19. gs. 60. gados tika veikta mācībspēku filtrācija, atstājot darbā tikai impērijai lojālos, bet kopš 1879. gada krievu valoda tika noteikta kā vienīgā piel̦aujamā apmācības valoda. ${ }^{25}$ Līdzīgi krievu valoda kā vienīgā apmācības valoda tika ieviesta līdz tam vācu valodā strādājušajā Tērbatas Universitātēe, ${ }^{26}$ kā arī Rīgas Politehniskajā institūtā (turpmāk - RPI), kur līdz 1896. gadam oficiālā mācību valoda bija vācu, pēc tam - krievu. ${ }^{27}$ Institūta profesori vērsās pie impērijas amatpersonām, lūdzot garantijas, lai, docēšanā nomainot vācu valodu ar krievu, viņiem tiktu saglabāti ieņemamie amati. ${ }^{28}$ Latvijas Valsts vēstures arhīva materiāli liecina par grūtībām, kādas bija līdz tam vācu valodā strādājušajam RPI 
akadēmiskajam personālam sazināties ar ierēdṇiem krievu valodā. Katra oficiālā vēstule krievu valodā, kuru augstskola saņēma no valsts, vispirms tika tulkota uz vācu valodu. ${ }^{29}$ Tāpat arī atbilde tika rakstīta vāciski, tad tulkota krieviski un tulkojums sūtīts atbildīgajiem ierēdñiem. ${ }^{30}$ RPI amatpersonas acīmredzami neprata valsts valodu pienācīgā līmenī, lai sazinātos, kur nu vēl, lai docētu šajā valodā.

20. gs. sākumā jaunās nacionālās valstis, kuras pašas bija lielā mērā vairāku paaudžu nacionālās inteligences materializēti sapņi, kā vienu no pirmajiem uzdevumiem sev izvirzija tieši nacionālas universitātes dibināšanu. ${ }^{31}$ Nacionālas universitātes dibināšana nozīmēja iespēju pārraut intelektuālās atkarības saites no vāciskās un krieviskās tradīcijas, lai veidotu kulturāli pašpietiekamu, neatkarīgu nākotni: pašiem sagatavot speciālistus, kas nepieciešami tēvzemes attīstībai, pašiem attīstīt un kopt zinātni, dziḷāk pētot jomas, kas ir svarīgas tieši savai nācijai. Turklāt docējot un zinātnē lietojot nacionālo valodu, šì valoda, kas iepriekš impērijā bija tikusi noniecināta, tika attīstīta, pierādot tās pilnvērtību un spēju funkcionēt visās sabiedrības darbības sfērās, tostarp visās zinātnes nozarēs. Nacionāla universitāte tika aplūkota kā nacionālas valsts kultūras un ekonomiskā uzplaukuma pamats.

\section{1918./1919. GADĀ LATVIJAS TERITORIJĀ DIBINĀTĀS AUGSTSKOLAS}

1918./1919. gadā tagadējā Latvijas teritorijā tika dibināti trīs valstiskumi. Turklāt šajā laikā tika apsvērtas arī citas valstiskumu idejas, kas virmoja gaisā, tā arī nemēginot tās realizēt, piemēram, baltu, t.i., latviešu un lietuviešu valsts. ${ }^{32}$ Lai cik nemierīgs laiks bija kara izskaṇa, tas nekavēja ikvienu spēku, kurš sajutās puslīdz drošs Latvijas teritorijas (vai vismaz daḷas teritorijas) pārvaldītājs, domāt par neatliekamiem uzdevumiem, visupirms dibinot savu augstskolu. 
"Pirmā pasaules kara izskaṇā (1917-1918) doma par "Livonijas ordeņa visvarenības” laikiem "atdzima” ar jaunu spēku. Šo pārliecību stiprināja ḳeizariskās Vācijas okupācijas karaspēka klātbūtne Baltijā, Krievijas impērijas sabrukums un bol̦ševiku nākšana pie varas Krievijā." ${ }^{33}$ Vācijas ķeizars atzina Vidzemes, Igaunijas, Rīgas un Sāmsalas suverenitāti 1918. gada 22. septembrī. ${ }^{34}$ Šì ziṇa līdz adresātiem nonāca tikai 17. oktobrī, un Apvienotās zemju padomes pastāvīgās komisijas locekḷi, balstoties uz 22. septembra Vācijas paziṇojumu, nolēma uzsākt darbu pie Baltijas hercogistes izveidošanas, aicinot tajā piedalīties arī Kurzemes hercogisti. ${ }^{35}$ Vienlaikus ar valsts veidošanu tika strādāts pie tai atbilstošas augstskolas. Tā Vācijas okupācijas vara 1918. gada oktobrī atjaunoja RPI kā Baltijas Tehnisko augstskolu (vācu: Baltische Technische Hochschule), pieskaņojot to Vācijas impērijas augstskolām izvirzītajām prasībām. Šis process varēja būt apgrūtināts, jo RPI, tāpat kā fabrikas un rūpnīcas, Pirmā pasaules kara laikā bija evakuēts dziḷāk impērijā prom no frontes līnijas, tāpēc Rīgā vairs nebija pieejami visi RPI resursi: ne materiālie, ne cilvēkresursi. Apmācības Baltijas Tehniskajā augstskolā bija paredzētas vācu valodā. Augstskolas statūtus 1918. gada 15. oktobrī apstiprināja vācu militārā pārvalde. ${ }^{36}$ 1918. gada 18. oktobrī laikraksts "Rigasche Zeitung" publicēja informāciju, ka ķeizars Vilhelms II ir nosūtījis apsveikuma telegrammu jaundibinātajai Baltijas Tehniskajai augstskolai. ${ }^{37}$

Tajā pašā laikā, kad notika mēǵinājumi atjaunot Livoniju, proti, 1918. gada rudenī latviešu nacionālpolitiskie spēki centās iegūt Vācijas atbalstu Latvijas neatkarībai, lai Vācija "neliktu šḳēršlus Latvijas tautai ceḷā uz tūlītēju neatkarīgas valsts celtniecības sākumu". ${ }^{38}$ Šo centienu rezultātā Latvijas Tautas padome 1918. gada 18. novembrī proklamēja Latvijas Republiku, apvienotu tās etnogrāfiskajās robežās (Kurzeme, Vidzeme un Latgale). ${ }^{39}$

Prof. Jānis Lazdiņš raksta: “Tieši tajā pašā dienā, kad tika proklamēta Tautas Padomes Latvijas Republika, "cita latviešu 
tauta” - lielinieki - Latvijas Sociāldemokrātijas 17. konferencē lēma, ka "Latvija ir savienota komūna, Krievijas Sociālistiskās Federatīvās Padomju Republikas sastāvdaḷa [un, ka] Latvijas jautājums proletariāta interesēs atrisināms vienīgi līdz ar proletariāta varas nostiprināšanos Latvijā, kas iespējams tikai starptautiskās sociālistiskās revolūcijas procesā'”' ${ }^{40}$ 1918. gada 17. decembrī tika izdots manifests par padomju varas dibināšanu Latvijā. ${ }^{41}$ 1919. gada 3. janvārī Rīgā ienāca lielinieku spēki, kas îsā laikā ieņēma gandrīz visu Latvijas teritoriju. Tādējādi drīz pēc Latvijas Republikas proklamēšanas tika pasludināta Latvijas Sociālistiskā Padomju Republika, kuru vadīja Pētera Stučkas valdība. ${ }^{42}$ Arī P. Stučkas valdība novērtēja izglītības valstisko nozìmi, un viens no pirmajiem tās lēmumiem bija reformēt izglìtības sistēmu atbilstoši marksistiskajiem uzskatiem: izglītībai ir jābūt bez jebkādas religijas ietekmes un pieejamai visiem, ievērojot pilnīgu vienlīdzību. Tāpēc tika noteikts, ka mācības visās skolās ir bez maksas un ticības mācība skolās tiek aizliegta. Visiem Latvijas skolu skolotājiem vajadzēja tikt ievēlētiem strādnieku un bezzemnieku deputātu padomēs. Nodarbības skolās bija paredzētas dzimtajā valodā. ${ }^{43}$ Analizējot normatīvos aktus, secināms, ka apmācības procesā nenotika pāreja uz latviešu valodu kā vienīgo apmācības valodu. Proti, reforma līdztekus krievu valodai kā izglìtības valodai izglìtības sistēmā ieviesa arī latviešu valodu. ${ }^{44}$

1919. gada 8. februārī ar P. Stučkas parakstītu dekrētu RPI (tobrīd Baltijas Tehnisko augstskolu) likvidēja: “.. viṇa profesori, asistenti, kalpotāji u.c. darbinieki skaitās (no šìs dienas) par atlaistiem." ${ }^{45}$ Tā vietā tika dibināta Latvijas Augstskola, kas tika nodota Izglītības komisariāta, ${ }^{46}$ kuru vadīja Jānis Bērziņš (18811938), ${ }^{47}$ pārziṇā. 1959. gadā iznākušajā grāmatā par Latvijas Universitāti nepieciešamība pēc jaunas augstskolas tika skaidrota šādi: "Lai gan Rīgas Politehniskais institūts atradās Latvijas teritorijā, to nevarēja uzlūkot par latviešu nacionālu augstskolu. Visas mācības tanī līdz 1896. gadam notika vācu valodā, bet pēc 
1896. gada - krievu valodā. [..] Un, kas īpaši svarīgi, institūts neplānoja un neapmierināja Latvijas vajadzības pēc speciālistiem medicīnā, humanitārajās u.c. zinātṇu nozarēs; šeit sagatavoja galvenokārt inženierus. Tāpēc Padomju Latvijas valdība nolēma neatjaunot Rīgas Politehnisko institūtu, bet dibināt jaunu augstskolu, kas gatavotu speciālistus tieši Latvijas Sociālistiskajai Padomju Republikai." ${ }^{48}$ Proti, arī LSPR tika izprasta nepieciešamība pēc augstākās izglītības latviešu valodā, kurā tiktu sagatavoti valstij vajadzīgie speciālisti. Tāpēc šajā ziṇā nav īpašu pretrunu ar konceptu, ka ikvienai valstij ir nepieciešama sava universitāte. Taču būtiska atškiriniba no klasiskai augstākajai izglītībai noteiktām prasībām bija iekḷauta reflektantu uzṇemšanas noteikumos, kas tika regulēti ar Izglīīibas komisariāta 1919. gada 8. februāra noteikumiem par Latvijas Augstskolu. Tie saturēja dzimumu vienlīdzības principu un piešķīra tiesības studēt ikvienam no 16 gadu vecuma, turklāt iekḷāva atrunu, ka studenti tiek uzṇemti "bez atestātiem par iepriekšējo izglītību, arī eksāmeni studentu uzņemšanai netiek ierīkoti”. ${ }^{49}$ Tādējādi tika īstenota vienlīdzīga pieeja augstākajai izglītībai visiem studētgribētājiem, arī tiem, kuri kara vai materiālo apstākḷu dẹ $\left.\right|^{50}$ nebija ieguvuši gimnāzijas izglītību. Proti, apmācībai augstskolā tika ieviests vecuma, nevis izglītības cenzs.

Atšķirībā no klasiskas universitātes, kurā tiek uzṇemti tikai gimnāziju absolventi, P. Stučkas valdība šādas prasības uzņemšanai Latvijas Augstskolā neizvirzīja. Arī augstskolas "skolotāju” atlasē juridiski netika noteikti ne izglītības, ne darba pieredzes kritēriji. Noteikumi par Latvijas Augstskolu ietvēra tikai prasību: "Latvijas Augstskolas skolotājus ievēl augstskolas komisija."51 Proti, lai gan tika dibināta augstskola, taču pēc reflektantiem un mācībspēkiem izvirzītajām prasībām nevar viennozīmīgi secināt, ka tā ir bijusi klasiska universitāte, t.i., augstākā mācību iestāde, kurā persona profesoru vadỉbā turpina izglītību pēc gimnāzijas sekmīgas pabeigšanas. Drīzāk tā bija vai nu savdabīga komunistu alternatīva klasiskai universitātei, kas nodrošina 
iespēju studēt visiem studētgribētājiem, vai arī tautas augstskolas modelis, proti, pieaugušo tālākizglìtības iestāde, kādas tika dibinātas, piemēram, Veimāras Republikā. ${ }^{52}$ Bija paredzēts, ka studenti var saṇemt ne tikai atestātu par pilnu izglìtību, bet arī apliecinājumus par atsevišķu studiju kursu noklausīšanos. ${ }^{53}$ Atšḳirīgais studentu zināšanu līmenis nenovēršami radīja problēmas studiju procesā. Lai gan Latvijas Augstskola darbojās tikai dažus mēnešus, tā saskārās ar ievērojamām grūtībām. "Atsevišķas nodarbības bija vāji apmeklētas, un zināšanu līmenis studentiem, no kuriem daudziem nebija vidējās izglītības, bija visai zems." ${ }^{4}$ Tāpat minētie noteikumi iekḷāva normu, ka lekcijas notiek latviešu un krievu valodā. ${ }^{55}$

1919. gada pavasarī Latvijā bija trīs valdības: sabiedroto, jo īpaši Lielbritānijas, atbalstītā Kārḷa Ulmaṇa (1877-1942) valdība (kopš 16. aprīla tā darbojās uz kug̣a "Saratov" Liepājas ostā), Rìdigera fon der Golca (Gustav Adolf Joachim Rüdiger Graf von der Goltz, 1865-1946) un vācbaltiešu atbalstītā Andrieva Niedras (1871-1942) valdība, kurai simpatizēja Vācija, un Padomju Krievijas atbalstītā P. Stučkas valdība. 1919. gada 22. maijā Rīga tika atbrīvota no lieliniekiem. ${ }^{56}$ Praktiski nekavējoties notika izmaiṇas arī augstākajā izglītībā. Mācības padomju Latvijas Augstskolā ilga līdz 1919. gada 21. maijam. ${ }^{57}$ Pēc Rīgas ieņemšanas tika atjaunota Baltijas Tehniskās augstskolas (bij. RPI) darbība, bet pēc Strazdumuižas pamiera 1919. gada jūlijā Latvijas Pagaidu valdība Baltijas Tehnisko augstskolu slēdza. ${ }^{58}$

\section{LATVIJAS UNIVERSITĀTES DIBINĀŠANA}

Latvijas tautai izdevās nosargāt 1918. gada 18. novembrī dibināto Latvijas Republiku, un sekoja Latvijas Augstskolas dibināšana. Ārkārtas apstākḷi Latvijas Republikā noteica to, ka Latvijas Augstskola juridiski netika dibināta ar speciālu parlamenta likumu vai valdības lēmumu, proti, dibināšanas dokumentiem, ar kādiem lepojas mierīgākā laikā dibinātās universitātes. 
Prasība pēc augstākās izglītības latviešu valodā pirmo reizi tika izvirzīta 1905. gadā skolotāju kongresā. ${ }^{59}$ Brūkot cara impērijai, līdztekus Latvijas valsts idejai veidojās arī LU ideja. 1917. gada maijā pie Vidzemes Pagaidu zemes padomes tika izveidota Latviešu augstskolas interesentu komisija Miķeḷa Valtera (1874-1968) vadībā. 1917. gada jūnijā Tērbatā (Tartu) latviešu skolotāju kongress nodibināja Augstskolas sekciju, kas izveidoja ipašu Latviešu augstskolas komiteju. ${ }^{60} 1919$. gada 11 . jūlijā Latviešu izglītības biedrības Augstskolas sekcija lēma par nepieciešamību izveidot nacionālu augstskolu. Aicinājums dibināt Latvijas augstskolu tika iesniegts toreizējam izglìtības ministram Kārlim Kasparsonam (1865-1962). ${ }^{61}$ Starpkaru laika prese liecina, ka 11. jūlijs ir ticis pieminēts kā būtisks datums Latvijas Universitātes organizēšanas procesu uzsākšanai. ${ }^{62}$ Arī pēc Otrā pasaules kara latviešu trimdas presē tika noraidìta doma, ka ideja par LU dibināšanu būtu saistāma ar Pētera Stučkas vārdu, jo: "Dāle [Pauls Dāle, 1889-1968] bija tas, kas 1916. g. februārī Maskavas latviešu Inteliǵences vakarā referēja par Latvijas augstskolas projektu, kur mācības notiktu latviešu valodā un piemērojoties dzimtenes īpatnējiem apstākḷiem."63

1919. gada 15. jūlijā K. Ulmanis Latvijas Tautas padomes sēdē referēja par valdībai nekavējoties veicamajiem darbiem. Viņš teica: "Kas attiecas uz Latvijas augstskolas darbību, tad nekavējoši jāstājas pie viņas organizēšanas darbiem. Augstskolas darbus iesāks uz jauniem pamatiem. Līdzšinējā Tehniskā augstskola ir jāpārṇem valdības rīcībā. Jāḳeras pie darba Latvijas universitātes atvēršanai. Vēl šinī rudenī mēs ceram to veikt."64 Par Latvijas augstskolas dibināšanu Latvijas Tautas padome lēma, atbalstot visu Ministru kabineta iesniegto darbības programmu kopumā. Balsošana notika, deputātiem pieceḷoties: 61 balss tika atdota par valdỉbas rīcības programmu un 22 - pret. $^{65}$ Tātad likumdevēja lēmums par LU dibināšanu datējams ar 1919. gada 15. jūliju. Turklāt likumdevējs, pēc valdības vadītāja expressis verbis pausta ierosinājuma, ir lēmis dibināt jaunu augstskolu, 
nevis atjaunot kādu no Latvijas teritorijā iepriekš pastāvējušām augstskolām.

Turpmāk sekoja valdības rīcība un augstskolas organizēšana. Lielā darbu apjoma dēl 1919. gada 16. jūlijā Tautas padome izdeva likumu par Ministru kabineta tiesībām Tautas padomes sesiju starplaikā, ja pastāv neatliekama vajadzība, izdot pagaidu rīkojumus ar likuma spēku. ${ }^{66}$ Nākamais juridiskais solis Latvijas Augstskolas dibināšanā bija valdības 1919. gada 3. augusta rīkojums "Par Rīgas Politehniskā Institūta pārņemšanu”. 67 Par "pamatu LU tiesiskai pastāvēšanai un viņas turpmākai izveidošanai" šis rīkojums atzīts LU Organizācijas padomes priekšsēdētāja, vēlākā rektora Ernesta Felsberga (1866-1928) un Organizācijas padomes sekretāra Kārḷa Oskara Kundziṇa (1883-1967) “Paskaidrojumos pie Latvijas Universitātes satversmes projekta". ${ }^{68}$

Rīkojumā tika noteikts, ka izveidojama speciāla komisija rīkojuma praktiskai izpildei, kurai:

1) jāpārņem RPI īpašums,

2) jāapspriež RPI nodaļu pārveidošana, lai tās atbilstu jaundibināmās Latvijas Augstskolas vajadzībām. ${ }^{69}$

Pēc rīkojuma tika uzsākta Latvijas Augstskolas dibināšana. Likumdevējs un valdība bija izvirzījuši uzdevumu atvērt Latvijas Augstskolu vēl 1919. gada rudenī. Tāpēc nekavējoties tika veidotas atbilstošas komisijas. Vispirms darbu uzsāka RPI Reorganizācijas komisija (turpmāk - Reorganizācijas komisija). Tās pirmā sēde notika 1919. gada 8. augustā. Paralēli tika veidotas un sāka darboties arī Latvijas Augstskolas dekānu padome, Saimniecības komisija un atsevišķu fakultāšu dibināšanas subkomisijas. ${ }^{70} 1919$. gada augustā bijušo RPI studentu kopējā sapulcē ievēlēja Studentu biroju, kas arī piedalījās Latvijas Augstskolas dibināšanas darbos. ${ }^{71}$ Reorganizācijas komisijas uzdevums bija ne tikai lemt, kā pārṇemt institūta resursus, bet arī apsvērt, kā likt pamatus jaunajai Latvijas Augstskolai uz pārņemto resursu bāzes. Jau pirmajā sēdē komisija lēma gan par to, kas ir pārņemams no RPI, proti, “vispirms atstāt visas 6 agrākās 
fakultātes: 1) agronomisko, 2) inženieru, 3) ķīmisko, 4) tirdzniecības, 5) arhitektu, 6) mehānikas", gan arī par to, kas vēl būtu nepieciešams jaunajai Latvijas Augstskolai, piemēram, "pārveidot līdzšinējo tirdzniecības fakultāti par ekonomisko-juridisko ar 4 gadīgu kursu". ${ }^{72}$ Tāpat šajā sēdē komisija sprieda par to, kam būs tiesības iestāties jaundibinātajā Latvijas Augstskolā. Profesors Pauls Valdens (1863-1957) pamatoja, ka augstskolas panākumu ķīla ir atbilstoši sagatavoti studenti, t.i., tādi, kas ir pabeiguši ǵimnāziju. P. Valdens uzsvēra arī "jaunekḷu un jaunavu vienlīdzīgu nostādīšanu" ${ }^{73}$ Vēl pirmajā sēdē tika apzinātas fakultātes, kuru izveidei būs nepieciešams piesaistīt jaunus resursus, piemēram, medicīnas un veterinārai fakultātei. ${ }^{74}$ Reorganizācijas komisijas galvenās izstrādātās vadlīnijas jaunajai augstskolai bija:

“1) Latvijas Augstskolai jābūt augstākai mācības iestādei valstī, kurai jāatrisina visi svarīgākie teorētiskie un praktiskie jautājumi, jāveic attiecīgi zinātniski pētījumi, jāsagatavo valstij derīgi zinātniskie un praktiskie darbinieki.

2) Turot augsti starptautiskās zinātnes cieṇu, visās studijās jācenšas ievērot mūsu Latvijas īpatnējie apstākḷi un prasības.

3) Mācības valodai jābūt latviešu, taču, pieaicinot līdzdarboties, pastāvīgi vai viesošanās veidā, kādus slavenus ārzemju vai nopelniem bagātus bijušos Rīgas Politehniskā Institūta profesorus, piel̦aujami izṇēmumi lietot krievu vai vācu valodu.

4) Par mācību spēkiem uzaicināmi tikai tie Rīgas Politehniskā Institūta nopelniem bagātie profesori, kuri nav izrādījuši pret Latvijas valsti naidu un necieņu, bet, jaunākus spēkus uzaicinot, priekšroka jādod latviešu valodas pratējiem un Latvijas apstākḷu pazinējiem."75

1919. gada 4. septembrī RPI Reorganizācijas komisiju pārveidoja par Latvijas Augstskolas Organizācijas komisiju (turpmāk - Organizācijas komisija). ${ }^{76}$

Likumdevējam vairākas reizes bija iespēja normatīvi ietekmēt augstskolas dibināšanas gaitu, jo 1919. gada septembra 
sākumā tam izskatīšanai tika iesniegts likumprojekts par grozījumiem valdības 3. augusta rīkojumā "Par Rìgas Politehniskā Institūta pārṇemšanu”. Vispirms 1919. gada 2. septembrī jautājums par RPI pārṇemšanas gaitu tika noṇemts no Tautas padomes dienas kārtības laika trūkuma dēḷ. ${ }^{77}$ Savukārt 5. septembrī Latvijas Tautas padomes ceturtās sesijas vienpadsmitajā sēdē tika izskatīts likumprojekts, kas paredzēja izdarīt grozījumus valdības 3. augusta rīkojumā "Par Rīgas Politehniskā Institūta pārņemšanu”. Par projektu referēja Tautas padomes loceklis Kārlis Dēḳens (1866-1942), kurš skaidroja, ka grozījumi nepieciešami, jo, lai gan rīkojums noteica vienas komisijas izveidošanu un piešķīra tai visai šauru kompetenci, taču dzīvē jau bija izveidotas arī padomes un apakškomisijas jeb, kā tās sauca laikabiedri, "subkomisijas", kas līdzdarbojās ne tikai RPI pārṇemšanā, bet arī Latvijas Augstskolas dibināšanā. Piedāvātajos grozījumos bija paredzēts skaidri noteikt, ka "politehniskais institūts ir pārveidojams par jauno Latvijas augstskolu”. ${ }^{78}$ Taču deputāti debatēs izcēla grozījumu projekta iekšèjās pretrunas un uzsvēra tā slikto kvalitāti. Ādolfs Klīve (1888-1974) norādīja, ka “augstskola ir pašlaik organizācijas stadijā un līdz nākošai sesijai viṇa būs pilnīgāk izveidojusies, tad nepieciešamības gadījumā varēs lemt". ${ }^{79}$ Kopumā deputāti atzina Latvijas Augstskolas organizācijas pasākumus par atbilstošiem un neredzēja vajadzību tajos lieki iejaukties ar papildus normatīvo regulējumu. Likumprojekts tika noṇemts no dienas kārtības. ${ }^{80}$

1919. gada 16. septembrī Izglīiības ministrijas telpās sanāca Organizācijas komisija prof. P. Valdena vadībā un lēma par prezidija un mācībspēku vēlēšanām, par studentu uzṇemšanu, sevišḳi uzsverot, ka "pie studentu uzṇemšanas Latvijas Augstskolā stingri ievērojams likums par pavalstniecību un atzīst principā, ka pie ārzemnieku uzņemšanas, Augstskolas knapo telpu dēḷ, vispirmā kārtā ievērojami Latvijai draudzīgo valstu pavalstnieki, kā leiši un igauṇi". ${ }^{81}$ Starp izskatāmajiem jautājumiem bija arī lemšana par Latvijas Augstskolas atklāšanas aktu. No protokola 
secināms, ka Augstskolas atklāšanas akta Rīcības komiteja nebija gatava ziņot, jo jautājumu pārcēla uz nākamo, proti, 19. septembra sēdi. ${ }^{82} 15$. septembrī sākās oficiāla studentu uzṇemšana Latvijas Augstskolā. ${ }^{83} 19$. septembra sēdē Organizācijas komisija secināja, ka ir pieteikušies 190 latvieši, 1 lietuvietis, 8 krievi, 7 vācieši, 139 ebreji. ${ }^{84}$ Augstskolas atklāšanas akta Rīcības komitejas sēdēs pēc ilgiem strīdiem par Latvijas Augstskolas dibināšanas pasākuma laiku, iespējamiem svinīgo runu teicējiem, norises vietu un lūgtajiem viesiem tika lemts svinības rīkot 28. septembrī visupirms augstskolas telpās, tad Nacionālajā operā. ${ }^{85}$ Ar 1919. gada 28. septembri noslēdzās Latvijas Augstskolas organizācijas darbu pirmais posms, un jau 29. septembrī sākās nodarbības 9 fakultātēs: Arhitektu, Inženieru, JuridiskiEkonomiskajā, Ķīmijas (un farmaceitu), Lauksaimnieku, Matemātikas-Dabas zinātṇu, Mehāniķu, Medicīnas, ValodnieciskiFilozofiskajā. Lemšana par Teolog̣ijas fakultātes dibināšanu turpinājās arī pēc augstskolas atklāšanas. ${ }^{86}$

Jau no pirmās dienas, kad valdības vadītājs K. Ulmanis Tautas padomei piedāvāja lemt par augstskolas dibināšanu, viņš paralēli lietoja divus jaunās augstskolas nosaukumus: Latvijas Augstskola un Latvijas Universitāte. ${ }^{87}$ Arī turpmāk tie tika lietoti līdztekus, lai gan oficiālajos dokumentos dominē Latvijas Augstskolas vārds. Pēdējā plašākā diskusija par nosaukumu bija vēl īsi pirms augstskolas dibināšanas 26. septembra Organizācijas komisijas sēdē. Tās rezultātā tika lemts latviešu valodā paturēt nosaukumu Latvijas Augstskola, bet starptautiski lietot nosaukumu latīṇu valodā Universitas Latviensis. ${ }^{88}$ Tomēr arī turpmāk abi nosaukumi latviešu valodā tika lietoti paralēli. Strādājot pie jaundibinātās augstskolas satversmes projekta, sāka dominēt nosaukums Latvijas Universitāte, lai gan veidlapās un zīmogos tika izmantots Latvijas Augstskolas vārds. ${ }^{89}$ Taču augstskolas pamatlikums tika izstrādāts ar nosaukumu "Latvijas Universitātes satversme". Latvijas Universitātes satversmes projektu Latvijas Augstskolas Organizācijas padome trešajā lasījumā pieṇēma 
1921. gada maijā un iesniedza valdībai tālākai virzībai. Par LU satversmes projekta avotiem Organizācijas padome minējusi: RPI 1896. gada nolikumu, RPI 1916. gada nolikuma projektu, Krievijas impērijas 1916. gada nolikumu par augstākajām tehniskajām mācību iestādēm, Parīzes Universitātes 1914. gada satversmi, 1920. gada Helsinku Universitātes satversmi u.c. avotus. ${ }^{90}$ Taču to vidū nav minēti ne Baltijas Tehniskās augstskolas, ne P. Stučkas dibinātās Latvijas Augstskolas normatīvie akti.

Viss Latvijas Universitātes dibināšanas process apliecina, ka Latvijas Republikā tika dibināta jauna universitāte, nevis pārņemta un turpināta P. Stučkas dibinātās Latvijas Augstskolas darbība. Par juridiski svarīgiem datumiem Latvijas Universitātes dibināšanā atzīstami: Latvijas Tautas padomes 1919. gada 15. jūlija lēmums par Latvijas Augstskolas dibināšanu un Latvijas Pagaidu valdības 3. augusta rīkojums (ar likuma spēku) "Par Rīgas Politehniskā Institūta pārņemšanu”, nozīmīgas ir arī Latvijas Tautas padomes 5. septembra debates, apspriežot grozījumu projektu valdības 3. augusta rīkojumā, kuras l̦auj secināt, ka likumdevējs atzina notiekošos LU dibināšanas procesus par atbilstošiem. Šie lēmumi deva juridisko pamatu Latvijas Universitātes atklāšanai 1919. gada 28. septembrī.

\section{KOPSAVILKUMS}

1. 1918./1919. gadā tagadējā Latvijas teritorijā tika dibināti trīs valstiskumi, un katrs no tiem dibināja savu augstskolu, izmantojot Latvijas teritorijā pēc evakuācijas palikušos Rīgas Politehniskā institūta resursus:

1.1. Vācijas okupācijas vara 1918. gada oktobrī atjaunoja RPI kā Baltijas Tehnisko augstskolu.

1.2. 1919. gada 8. februārī ar P. Stučkas parakstītu dekrētu tika dibināta padomju Latvijas Augstskola.

1.3. Latvijas Tautas padome 1919. gada 15. jūlijā lēma par Latvijas Augstskolas dibināšanu. 
2. Vērtējot P. Stučkas dibināto Latvijas Augstskolu, secināms, ka atbilstoši Izglītības komisariāta 1919. gada 8. februāra noteikumiem tika īstenota vienlīdzīga pieeja augstākajai izglītībai visiem studētgribētājiem, arī tiem, kam nebija iegūta ǵimnāzijas izglītība. Tas neatbilst augstākajai izglītībai izvirzāmajām prasībām, proti, ka augstākā izglītība ir nākamais soli pēc pabeigtas vidējās izglītības. Autore secina, ka P. Stučka dibināja nevis klasisku universitāti, bet marksistiskajai ideologijai atbilstošu alternatīvu augstskolu vai arī tautas augstskolu, kurā lekcijas notika latviešu un krievu valodā.

3. Latvijas Tautas padome 1919. gada 15. jūlijā lēma dibināt jaunu Latvijas Augstskolu, nevis atjaunot kādu no iepriekš Latvijas teritorijā pastāvējušajām. Tāpēc Latvijas Pagaidu valdība 1919. gada 3. augustā izdeva rīkojumu (ar likuma spēku) "Par Rīgas Politehniskā Institūta pārṇemšanu”, kam sekoja RPI pārņemšanas un Latvijas Augstskolas organizācijas darbi.

4. Latvijas Tautas padomes dienas kārtībā 1919. gada 2. septembrī un 5. septembrī bija likumprojekts, kas paredzēja izdarīt grozījumus Latvijas Pagaidu valdības 3. augusta rīkojumā "Par Rīgas Politehniskā Institūta pārṇemšanu”. Deputāti debatēja par likumprojektu un atzina, ka Latvijas Augstskolas organizācijas darbos nav nepieciešama papildus likumdevēja iejaukšanās, un likumprojekts tika noṇemts no dienas kārtības. Līdz ar to likumdevējs atzina valdības rīcību augstskolas dibināšanā par atbilstošu.

5. Latvijas Augstskolas dibināšanas process noslēdzās 1919. gada 28. septembrī ar svinīgo atklāšanas aktu. Latvijas Augstskola bija pirmā augstākās izglītības iestāde - universitāte, kurā apmācības valoda bija latviešu valoda.

6. Atbilstoši mūsdienu izpratnei par augstāko izglītību un universitātes misiju valstī universitātes tiek aplūkotas kā sabiedriski un valstiski nozīmīgi izglītības un zinātnes centri, kas kalpo par nācijas pilnvērtīgas, vispusīgas attīstības pamatu. Pēc autores domām, augstākā izglītība valsts valodā ir valstiski svarīga, jo 
sekmē valsts valodas attīstību un tālāko tās pielietojumu visās dzīves jomās. Jaunajai Latvijas Republikai bija nepieciešama nacionāla universitāte. Tāpēc nacionālajā presē Latvijas Augstskolas atklāšana pēc nozīmes tika salīdzināta ar Latvijas valsts proklamēšanu un vērtēta kā nācijas uzplaukuma pamats, pielīdzinot to nacionālās pašapziņas simbolam "Gaismas pilij”.

7. Nepieciešams veikt labojumus Latvijas Universitātes Satversmes Preambulā, kas ietver LU dibināšanas vēsturiskos aspektus, lai tā juridiski atspoguļotu vēsturiski korektus faktus, proti, normatīvu lēmumu par Latvijas Universitātes dibināšanu pieñēma Latvijas Tautas padome 1919. gada 15. jūlijā.

\section{ATSAUCES UN PIEZĪMES}

1 Latvijas Republikas Augstākās Padomes 1991. gada 18. septembra lēmums Par Latvijas Universitātes Satversmes apstiprināšanu. Pieejams: https:// likumi.lv/ta/id/70441-par-latvijas-universitates-satversmes-apstiprinasanu (skatîts 26.09.2019.).

2 Pētījums veikts, gatavojoties uzstāties Latvijas Universitātes Juridiskās fakultātes 7. starptautiskajā zinātniskajā konferencē "Tiesību zinātnes uzdevumi, nozīme un nākotne tiesību sistēmās" 2019. gada 16. oktobrī.

3 Jānis Jurgens (sast.) (1959). Pētera Stučkas Latvijas Valsts universitāte 40 gados (1919-1959). Rìga: Latvijas Valsts izdevniecỉba, 3.-4. lpp.

4 Ilgonis Bite. “Celdamās augstāki”. P. Stučkas Latvijas Valsts universitātei 70. Literatūra un Māksla, 04.02.1989., 2. lpp.

5 Ernests Felsbergs, Kārlis Kundziņš (b.g.). Paskaidrojumi pie Latvijas Universitātes satversmes projekta. Latvijas Nacionālā arhīva Latvijas Valsts vēstures arhīvs (Rīga, turpmāk: LNA LVVA), 7427-6-325, 80. lp.; arī Latvijas Universitāte 1919-1929 (1929). Rīga: Latvijas Universitātes izdevums, 19.20. lpp.

6 Velta Ozola. Latvijas universitātei 55 gadi. Latvija Amerikā, 28.09.1974., 9. lpp.

7 Latvijas Republikas Augstākās Padomes 1991. gada 18. septembra lēmums Par Latvijas Universitātes Satversmes apstiprināšanu.

8 Latvijas Universitātes Satversme, pieñemta LU Satversmes sapulces sēdē 29.03.1996., un grozijumi, kas pieņemti LU Satversmes sapulces sēdē 16.12.1996., LU Satversmes sapulces sēdē 10.05.2001., LU Satversmes sapulcē 22.02.2006. Pieejams: https://likumi.lv/doc.php?id=46864 (skatīts 26.09.2019.). 
9 LU laika gaitā. Latvijas Universitātes mājaslapa. Pieejams: https://www.lu.lv/ par-mums/vesture/lu-laika-gaita/ (skatīts 08.08.2019.).

10 Turpat.

11 Latvijas Sociālistiskās valdības 1919. gada 8. februāra dekrēts "Par Latvijas augstskolas dibināšanu”. Cīna, 08.02.1919., 1. lpp.

12 Latvijas Universitāte 1919-1929 (1929). Rīga: Latvijas Universitātes izdevums; Ludvigs Adamovičs, Jūlijs Auškāps, Kārlis Straubergs (1939). Latvijas Universitāte 20 gados 1919-1939. I-II daḷa. Rīga: Latvijas Universitāte; Jānis Jurgens (sast.) (1959). Pētera Stučkas Latvijas Valsts universitāte 40 gados (1919-1959). Rīga: Latvijas Valsts izdevniecība; utt.

13 Piemēram, 1919. gada 1. septembrī tika izveidota Latvijas Augstskolas Organizācijas komisija, sk.: Felsbergs, Kundziņš. Paskaidrojumi pie Latvijas Universitātes satversmes projekta. Arī presē tika rakstīts par Latvijas Augstskolas dibināšanu, piemēram: Latvijas Augstskola. Sociāldemokrāts, 29.09.1919., 1. lpp.

14 LNA LVVA, 7427-6-37a, 79.-80. lp.

15 Karl-Heinz Schmidt (2015). University studies at Hardenberg's and Humboldt's time and the professionalization of university studies today. In: Jürgen Georg Backhaus (ed.). The University According to Humboldt: History, Policy, and Future Possibilities. Erfurt: Springer, pp. 53-65, here p. 58.

16 Latviešu tiesību zinātnē šīs idejas izklāstīja, piemēram: Kārlis Dišlers (1932). Tautu pašnoteikšanās principa tiesiskais saturs. Rīga: Latvijas Universitāte, 2. lpp.

17 Igors Vārpa (2012). Cel̦š uz Latvijas valsti, 1919-1922. Rīga: Jumava, 5. lpp.

18 Mik̦elis Valters (1914). Mūsu tautības jautājums. Domas par Latvijas tagadni un nākotni. Rīga: A. Valters, J. Rapa un biedri, 36. lpp.

19 Theodor Raiser (1999). Das lebende Recht. Rechtssoziologie in Deutschland. Baden-Baden: Nomos Verlag, S. 139.

20 Niklas Luman (2004). Obshchestvo kak sistema. Moskva: Logos, s. 45.

21 Curt Lutz Lässig (1980). Deutsch als Gerichts- und Amtssprache. Berlin: Duncker \& Humblot, S. 11-15.

22 Jānis Čakste. Mūsu gaismas pils. Brīvā Zeme, 28.09.1919., 1. lpp.

23 P.D. Latvijas Augstskolu atklājot. Brīvā Zeme, 28.09.1919., 1. lpp.

24 Terminu "mazās tautiṇas" autore patapinājusi no Miḳeḷa Valtera (18741968) grāmatas Mūsu tautības jautājums. Domas par Latvijas tagadni un nākotni, 36. lpp. Tas ir adekvāts, lai runātu par impērijās dzīvojošu minoritāšu tiesībām to apdzīvotajās teritorijās, pirms vēl bija izveidotas minoritāšu tiesības un jēdziens minoritāte.

25 Malte Rolf (2014). Imperiale Herrschaft im Weichselland: Das Königreich Polen im Russischen Imperium (1864-1915). Oldenbourg: de Gruyter, S. 35.

26 Peeter Järvelaid (2015). Eesti õigusteaduse ja õigushariduse ajalugu. Tallinn: Argo, pp. 86-87. 
27 Alīda Zigmunde (2006). Pedagog̣iskās darbības saturs Rìgas Politehnikumā un Rìgas Politehniskā institūtā (1862-1919). Promocijas darbs. Rīga: Latvijas Universitāte, 41 . lpp.

28 LNA LVVA, 7175-3-16, 137. lp.

29 LNA LVVA, 7175-1-22, 100., 101. lp.

30 Turpat.

31 Čakste. Mūsu gaismas pils, 1. lpp.

32 Jānis Lazdiṇš. Konstitucionālisma pirmsākumi un nerealizētie valstiskumi Latvijā. Jurista Vārds, 11.06.2013. Pieejams: https://juristavards.lv/doc/257350konstitucionalisma-pirmsakumi-un-nerealizetie-valstiskumi-latvija/ (skatīts 10.07.2019.).

33 Turpat.

34 Wilhelm I. Graf von Hertling. Anerkennung der Unabhängigkeit von Livland, Estland, Riga und Oesel durch das Deutsche Reich. Rigasche Zeitung, 19.10.1918., S. 1.

35 Lazdiņš. Konstitucionālisma pirmsākumi un nerealizētie valstiskumi Latvijā.

36 Alīda Zigmunde (2001). Baltijas Tehniskā augstskola. No: Zinātņu vēsture un muzejniecība: LU raksti. 639. sēj. Rīga: Latvijas Universitāte, 36.-40. lpp., šeit 36. lpp.

37 Kaisertelegramm an die Baltische Technische Hochschule. Rigasche Zeitung, 18.10.1918., S. 1.

38 LNA LVVA, 6033-1-35, 57. lp.

39 1918. gada 18. novembra Latvijas Tautas Padomes uzsaukums: Latvijas pilsoņiem! No: Jānis Lazdiņš (sast.) (2015). Latvijas valsts tiesību avoti. Valsts dibināšana - neatkarības atjaunošana: Dokumenti un komentāri. Rìga: Tiesu namu aǵentūra, 54. lpp.

40 Lazdiņš. Konstitucionālisma pirmsākumi un nerealizētie valstiskumi Latvijā.

41 Jurgens. Pētera Stučkas Latvijas Valsts universitäte 40 gados (1919-1959), 7. lpp.

42 Daina Bleiere, Ilgvars Butulis, Inesis Feldmanis, Aivars Stranga (2005). Latvijas vēsture. 20. gadsimts. Otrais papildinātais izdevums. Rīga: Jumava, 113. lpp.

43 Jurgens. Pētera Stučkas Latvijas Valsts universitāte 40 gados (1919-1959), 8. lpp.

44 LSPR Izglītîbas komisariāta 1919. gada 8. februāra noteikumi par Latvijas Augstskolu. Cìna, 08.02.1919., 1. lpp.

45 Latvijas Sociālistiskās valdības 1919. gada 8. februāra dekrēts "Par Latvijas augstskolas dibināšanu”. Cìña, 08.02.1919., 1. lpp.

46 Turpat.

47 Heinrihs Jubels (galv. red.) (2002). Latvijas enciklopēdija. 1. sēj. Rīga: Valērija Belokona izdevniecība, 632.-633. lpp. 
48 Jurgens. Pētera Stučkas Latvijas Valsts universitāte 40 gados (1919-1959), 9. lpp.

49 LSPR Izglītības komisariāta 1919. gada 8. februāra noteikumi par Latvijas Augstskolu. Cìna, 08.02.1919., 1. lpp.

50 Pirms, dibinot LSPR, tika pasludināta bezmaksas izglītība, par mācībām bija jāmaksā.

51 4. pants. LSPR Izglītības komisariāta 1919. gada 8. februāra noteikumi par Latvijas Augstskolu. Cìna, 08.02.1919., 1. lpp.

52 Günther Dohmen (2013). Volkshochschulen. In: Rudolf Tippelt, Aiga von Hippel (Hrsg.). Handbuch Erwachsenenbildung/Weiterbildung. Erfurt: Springer, S. 408-409.

53 LSPR Izglītības komisariāta 1919. gada 8. februāra noteikumi par Latvijas Augstskolu. Cīna, 08.02.1919., 1. lpp.

54 Jurgens. Pētera Stučkas Latvijas Valsts universitāte 40 gados (1919-1959), 17. lpp.

55 14. pants. LSPR Izglītības komisariāta 1919. gada 8. februāra noteikumi par Latvijas Augstskolu. Cīna, 08.02.1919., 1. lpp.

56 Bleiere, Butulis, Feldmanis, Stranga. Latvijas vēsture. 20. gadsimts, 117. lpp. Jurgens. Pētera Stučkas Latvijas Valsts universitāte 40 gados (1919-1959), 18. lpp.

58 Zigmunde. Baltijas Tehniskā augstskola, 36.-40. lpp.

59 Andrejs Vičs. Latvijas skolotāju kongress. (No 27. līdz 31. dec. 1920.). Izglitības Ministrijas Mēnešraksts, 01.02.1921., 130.-131. lpp. Ozola. Latvijas universitātei 55 gadi, 9. lpp.

Šodien Latvijas universitātes idejiska dzimšanas diena. Rìts, 11.07.1939., 17. lpp.

62 Turpat.

63 Ozola. Latvijas universitātei 55 gadi, 9. lpp.

Kārlis Ulmanis. Runa Latvijas Tautas Padomes trešās sesijas otrā sēdē. 1919. gada 15. jūlijā. Latvijas Tautas Padomes sēdes, 13.07.1919., 108. lpp. Latvijas Tautas Padomes trešās sesijas 1919. gada 15. jūlija otrās sēdes stenogramma. Latvijas Tautas Padomes sēdes, 13.07.1919., 121. lpp.

Latvijas Tautas Padomes 1919. gada 16. jūlija Likums par Ministru kabineta tiesību izdot pagaidu rīkojumus. Latvijas Pagaidu Valdības Likumu un Rīkojumu Krājums, Nr. 7, 10.08.1919., 90. lpp. Tautas padomes debates par šo likumu sk.: Latvijas Tautas padomes trešās sesijas 1919. gada 16. jūlija trešās sēdes stenogramma. Latvijas Tautas Padomes sēdes, 13.07.1919., 131. lpp.

67 1919. gada 3. augusta rīkojums Par Rīgas Politehniskā Institūta pārṇemšanu. Latvijas Pagaidu Valdības Likumu un Rīkojumu Krājums, Nr. 7, 10.08.1919., 96. lpp.

68 Felsbergs, Kundziņš. Paskaidrojumi pie Latvijas Universitātes satversmes projekta, 80. lp. 
69 1919. gada 3. augusta rīkojums Par Rīgas Politehniskā Institūta pārņemšanu.

70 Felsbergs, Kundziņš. Paskaidrojumi pie Latvijas Universitātes satversmes projekta, 80. lp.

71 Studentu birojs vēlāk pārtapa Studentu pagaidu padomē, un tikai 1920. gada 12. decembrī tika likumīgi ievēēēta Studentu padome. Sk.: Studentu padomes darbības pārskats. LNA LVVA, 7427-6-37a, 350. lp.

72 Rīgas Politehniskā institūta reorganizācijas komisijas 1919. gada 8. augusta sēdes protokols Nr. 1. LNA LVVA, 1632-2-603, 1. lp.

73 Turpat.

74 Turpat.

75 Pauls Lejinšs. Latvijas Augstskola. Izglìtîbas Ministrijas Mēnešraksts, 01.01.1920., 75. lpp.

76 1919. gada 28. novembrī to pārveidoja par Latvijas Augstskolas Organizācijas padomi. Sk.: Felsbergs, Kundziņš. Paskaidrojumi pie Latvijas Universitātes satversmes projekta, 80. lp.

77 1919. gada 2. septembra Latvijas Tautas Padomes ceturtās sesijas desmitās sēdes stenogrammas, Nr. 4, 164. lpp.

78 1919. gada 5. septembrī Latvijas Tautas Padomes ceturtās sesijas vienpadsmitajā sēdē priekšlikums par grozījumiem 1919. gada 3. augusta rīkojumā "Par Rīgas Politehniskā Institūta pārṇemšanu". Latvijas Tautas Padomes sēdes stenogrammas, Nr. 4, 313. lpp.

79 Ādolfs Klīve. Replika 1919. gada 5. septembrī Latvijas Tautas Padomes ceturtās sesijas vienpadsmitajā sēdē debatēs par grozījumiem 1919. gada 3. augusta rīkojumā "Par Rīgas Politehniskā Institūta pārņemšanu". Latvijas Tautas Padomes sēdes stenogrammas, Nr. 4, 313. lpp.

80 Turpat, 314. lpp.

81 LNA LVVA, 1632-2-603, 23. lp.

82 Turpat.

83 Ernests Laube. Paziņojums. Lūgumrakstus dēḷ iestāšanās Latvijas Augstskolā sāks pieņemt Augstskolas kancelejā 15. septembrī š.g. Valdības Vēstnesis, 07.09.1919., 3. lpp.

84 LNA LVVA, 1632-2-603, 25. lp.

85 Turpat, 27.-29. lp.

86 Lejinšs. Latvijas Augstskola, 75. lpp.

87 Ulmanis. Runa Latvijas Tautas Padomes trešās sesijas otrā sēdē. 1919. gada 15. jūlijā, 108. lpp.

88 LNA LVVA, 1632-2-603, 36. lp.

89 LNA LVVA, 7427-6-215, 39. lp.

90 LNA LVVA, 7427-6-375, 80., 81. lp. 


\section{LEGAL ASPECTS OF THE ESTABLISHING THE UNIVERSITY OF LATVIA}

\section{Sanita Osipova}

Dr. iur., professor, Faculty of Law, University of Latvia.

Research interests: history of law, legal ethics, legal sociology. Currently is working at the collective monograph Rights in Information Society.

Year 2019 is the year of the anniversary of the University of Latvia, therefore, within the framework of study, the legal aspects of the foundation of the University of Latvia and its social-political significance in the Republic of Latvia were investigated. The Preamble of the Constitution of the University of Latvia and other sources provide a two-step division of the foundation of the University: a decree on the foundation was signed by Pēteris Stučka on 8 February 1919 but the actual opening was performed by Jānis Čakste on 28 September. The study results show that this Soviet-time concept about the foundation of the UL is false. The People's Council of Latvia, on 15 July 1919, decided to found a new Higher School of Latvia rather than renew one of the higher schools previously existing in the territory of Latvia. The decision of the People's Council of Latvia along with the order by the Provisional Government, on 2 August 1919, for implementation of this decision, are to be considered the legal basis of the foundation of the University of Latvia.

Key words: national higher school, establishing the University of Latvia.

\section{Summary}

In $1918 / 1919$, three statehoods were established in what is now the territory of Latvia, and each of the states founded its own higher school using the Riga Polytechnical Institute's (RPI) resources that had remained in the territory of Latvia after the evacuation. In October 1918, the German occupation power renewed RPI as the Baltic Technical Higher School. On 8 February 1919, the Soviet Latvian Higher School was founded by a decree signed by Pēteris Stučka. On 15 July 1919, the People's Council of Latvia decided to establish the Higher School of Latvia.

The analysis of the Latvian Higher School founded by Pèteris Stučka reveals that, pursuant to the Commissariat of Education Regulation of 8 February 1919, equal access to higher education was ensured for all those willing to study, including those who had not received secondary education. This contradicts the requirements for higher education and 
raises doubts as to whether a higher school in the traditional sense of the word had been established. The author concludes that what Pēteris Stučka founded was not a classical university but either a Marxist-compatible alternative to the classical "bourgeois university" or a people's higher school where lectures were held in Latvian and Russian.

On 15 July 1919, the People's Council of Latvia decided to establish a new Latvian higher school rather than renew one of the higher schools previously existing in the territory of Latvia. For this purpose, on 3 August 1919, the Government issued the order "On taking over Riga Polytechnical Institute", which was followed by activities for the takeover of RPI and the establishing of the Higher School of Latvia.

Put on the agenda of the People's Council of Latvia on 2 and 5 September 1919 was a draft law that was intended to amend the order of 3 August "On taking over Riga Polytechnical Institute". The members of the Council debated on the draft law and found that no additional interference on the part of the Government in the activities for establishing the Higher School of Latvia was necessary. Thus, the draft law was taken off the agenda.

The process of establishing the Higher School of Latvia concluded on 28 September 1919 with a formal opening event marking the establishment of the first higher education institution - university - in which the language of instruction was Latvian. The Higher School of Latvia met the criteria set for universities, as it was stipulated that the School would only admit candidates who have a secondary (gymnasium) education, and also the teaching staff were required to be appropriately qualified.

Higher education in the state language is of national importance because it is instrumental in the development of the state language and its further use in all spheres of life; in our modern understanding of the mission of higher education and university in a state, universities are educational and academic centres of social and national importance, serving as a basis for full and comprehensive development of the nation. In the national press, the significance of opening the Higher School of Latvia was compared to that of the proclamation of the Latvian state and viewed as a basis for the nation's well-being, as it was equated to the "Castle of Light" - a symbol of national identity. 